\title{
MANAGEMENT APPROACHES FOR INDUSTRY 4.0 - THE ORGANIZATIONAL CULTURE PERSPECTIVE
}

\author{
Hana MOHELSKA (D) ${ }^{*}$, Marcela SOKOLOVA (D)2 \\ ${ }^{1,2}$ Department of Management, Faculty of Informatics and Management, \\ The University of Hradec Kralove, Hradec Kralove, Czech Republic
}

Received 01 May 2018; accepted 16 July 2018

\begin{abstract}
The Industry 4.0 concept describes a decentralized production chain that extends from design to the supply chain, production, distribution as well as customer service. Cyber Physical Systems (CPS) employ software and internet-connected machines that communicate in real-time to reduce error rates and increase efficiency. The basis is the co-operation of separate control units that are capable of autonomous decision-making, managing the assigned technological unit and in particular becoming an independent and full member of comprehensive production units. The Industry 4.0 concept requires continuous innovation and education that not only depends on the peoples' skills but also on organizational culture. Appropriate managerial approaches play a vital role in the development of organizational culture. Most studies discuss technical aspects, but do not pay attention to managerial approaches and organizational culture, which are a major factor influencing the success of this concept. The aim of the paper is to examine the level of organizational culture in the Czech Republic and to seek appropriate managerial approaches for the development of organizational culture that can support the environment for innovation in the organization and therefore facilitate the entrepreneurship in the Industry 4.0 concept. A partial goal will be, among other things, to identify the implications of Industry 4.0 for human resources. In order to determine organizational culture in organizations, a large study was carried out in the form of a questionnaire survey - the Czech translation of Wallach's Questionnaire (1983). According to the findings, the respondents perceive the organizational culture in the organizations under review is more bureaucratic and supportive than innovative. In their view the signs of innovative culture are not so striking. It is necessary to change managerial approaches to support innovative solutions.
\end{abstract}

Keywords: Industry 4.0, organizational culture, managerial approaches, industrial revolution, Czech Republic, bureaucratic culture, innovative culture.

JEL Classification: M14, M54.

\section{Introduction}

The world is at the threshold of the fourth industrial revolution that has already begun. This is the fourth milestone, which fundamentally changes the working conditions of organizations.

*Corresponding author. E-mail: hana.mohelska@uhk.cz

This is an Open Access article distributed under the terms of the Creative Commons Attribution License (http://creativecommons. org/licenses/by/4.0/), which permits unrestricted use, distribution, and reproduction in any medium, provided the original author and source are credited. 
Period of industrial revolutions (Pagáč, 2015):

- The first industrial revolution refers to the period at the end of the 18th century, which was made possible by the development of coal mining, the steam machinery and the introduction of the first machines into production;

- The second industrial revolution took place around the beginning of the 20th century and its trigger was the introduction of electricity and the first lines of mass production are typical of it;

- The third industrial revolution dates back to the 1970s and is marked by the automation of production and the introduction of the first information systems and technologies;

- The fourth industrial revolution - Industry 4.0 takes place at the beginning of the 21 st century and is characterized by strong robotics, machine autonomy, use of the Internet of things and artificial intelligence.

Industry 4.0 is a designation for automation of production and change in the labor market that it will bring. Industry 4.0 is based on the boom of digitization, robotics and automation, and it is characterized by a blend of information technologies and production processes and in an intelligent way that is typical of autonomous machines. It is largely based on the Internet of things, which has brought about a number of changes to manufacture and maintenance in the industry, from the reduction of the production cycle to the automation of machinery and equipment maintenance.

The fourth industrial revolution means even more complex interconnection of the entire production process, from development, production, and distribution to after-sales services. It employs autonomous robots that control and regulate themselves through network connections and various sensors (cameras, room sensors, temperature sensors, etc.).

In production, this concept represents a revolutionary loss of human labor, as robots will take over larger part of the work that only could have been performed by humans. Devices and also products themselves or even semi-finished products, will be equipped with chips that carry key information about how they are to be processed, when they are to be processed and the like. Storage systems will behave more or less by themselves; they will send the order themselves if additional material is needed. Lines will be much easier to reorganize, making it possible to produce cheaper, small series, or even to produce at the cost of today's largevolume products.

Most studies discuss technical aspects, but do not pay attention to managerial approaches and organizational culture, which are a major factor influencing the success of this concept. Implementing the Industry 4.0 concept requires continuous innovation and education that not only depend on people's abilities but also on organizational culture. Appropriate managerial approaches play a vital role in the development of organizational culture.

The aim of the paper is to investigate the level of organizational culture in the Czech Republic and to seek appropriate managerial approaches to the development of organizational culture that can support the environment for innovation and therefore facilitate the entrepreneurship in the Industry 4.0 concept. A partial goal will be, among other things, to identify the implications of Industry 4.0 on human resources. 


\section{Theoretical framework of work}

Theoretical background of industry 4.0 and organizational culture is explained in this chapter.

\subsection{Actuality and relevance}

In a globalized world with particularly interconnected procedures, companies have to find ways of coping with an increasing number of challenges. With competitors from all over the globe, innovation ability and a quick time-to-market end up essential. In addition, step-bystep markets have become risky and heterogeneous due to constantly changing customer expectations and requirements; these include custom designed products on call for. Clever manufacturing structures are put into place to create the required flexibility and ability, so that they satisfy expectations (Háša \& Brunet-Thornton, 2017). Simple and monotonous procedures are being automated at the same time as other approaches prove to be extra complex and intertwined. Therefore, qualification strategies for modern-day personnel are required. Do you mean: Employees want to prove that they are able to take on extra strategic, coordinating and innovative sports. Similarly, changing social values of personnel and demographic exchange toward an expanding ageing society creating a similar need for action (Hecklau, Galeitzke, Flachs, \& Kohl, 2016).

From a strategic perspective, literature is in agreement that Industry 4.0 has far-reaching implications for business models. These comprise of both change in newly emerged business models and in already established business models. Recent research emphasizes the potential of business model innovation based on digital-technology, and data-centred business logic. Research identifies some of the most important areas regarding Industry 4.0-related business model changes; for example data-based value creation and propositions, the transition from product to system offerings, enhanced customization, intensified customer relationships, IT and software know-how as key resources, and increasing inter-connection as well as collaboration with key-partners (Arnold, Kiel, \& Voigt, 2016).

Data plays a crucial role in this context, as an increasing fusion of physical products and services with digital, data-centred enhancements and solutions is likely. A consequent orientation towards services is very likely and this accelerates the vanishing separation between product manufacturing and the provision of services. Companies can use these services to offer customized solutions and a high degree of individuality (Rennung, Luminosu, \& Draghici, 2016).

Significant opportunities for the global competitiveness of manufacturing companies' are expected. The literature is generally in agreement that business model innovation is a major source of unique selling propositions and strategic differentiation, particularly in highly competitive market environments (Schneider \& Spieth, 2013; Voigt, Buliga, \& Michl, 2017).

\subsection{The definition of Industry 4.0}

The idea of Industry 4.0 describes the growing digitization of the entire fee chain and the resulting inter-connection of people, gadgets and systems through real-time facts exchange. As a consequence of that inter-connection, products, machines and procedures are prepared 
with artificial intelligence and are able to conform independently to the environment's spontaneous adjustments. In addition, smart items emerge embedded in broader systems, which beautify the advent of flexible, self-controlling production structures. There are various application fields for clever gadgets and systems; nonetheless, the main focus lies with commercial packages (Qin, Liu, \& Grosvenor, 2016). Industry 4.0 refers to recent technological advances where the internet and supporting technologies (e.g. embedded systems) serve as a backbone to integrate physical objects, human actors, intelligent machines, production lines and processes across organizational boundaries to form a new kind of intelligent, networked and agile value chain (Prause \& Atari, 2017).

The German interpretation of smart production, Industry 4.0, goes even further than these objectives by additionally tackling energy and resource efficiency, as well as increasing productivity and shortening innovation and time-to-market cycles (Kagermann, Wahlster, \& Helbig, 2013). Internet-based linked machine-to-machine interaction paves the way to networked manufacturing systems and cross-company production processes that enable the design and control of the product's entire supply chain during its full life time (Bauer, Schlund, Marrenbach, \& Ganschar, 2014; Brettel, Friederichsen, Keller, \& Rosenberg, 2014).

\subsection{The definition of organizational culture}

"Organizational or corporate culture is the pattern of values, norms, beliefs, attitudes and assumptions that may not have been articulated but shape the ways in which people in organizations behave and things get done. Values refer to what is believed to be important about how people and organizations behave. Norms are the unwritten rules of behavior" (Armstrong, 2006).

E. H. Schein (2004) defines organizational culture as a "deeper level of basic assumptions and beliefs that are shared by the company's employees: it acts subconsciously and forms a basis for reflection of the company, both internally and externally" (Schein, 2004).

"Culture is the unique whole - comprising shared ideas, customs, assumptions, expectations, philosophy, traditions, mores, values and understanding - that determines how a group of people will behave. When one talks of a corporation's culture, one means that complex interrelated whole of standardized, institutionalized, habitual behavior that characterizes that firm" (Osborne \& Brown, 2005).

Wallach (1983) says there is no good or bad culture. Organizational culture becomes effective when it is able to support the mission, goals and strategies of organization (Wallach, 1983). In addition Widyarini (2009) also mentions that in order to be effective, culture must not only be efficient, but should also match the business needs, the company and its employees. Everyone is aware of the importance of culture and how culture is embraced (Mustafa Elqadri \& Priyono, 2015). Wallach (1983) mentions that there are three types of organizational cultures, bureaucratic culture, innovative culture and supportive culture (Wallach, 1983). Handoko, Setiawan, and Surachman (2011) revealed that supportive, innovative and bureaucratic culture has a relationship with employees work performance with varying results. Additionally, Handoko et al. (2011) also said that in order to improve employee performance, it is necessary to pay attention to an innovative and empowering culture. Innovative 
culture boosts creativity and results-oriented, stimulation and challenge became the driving performance. Basically organizational culture is closely related to behavior in the workplace or particularly in this case, in individual performance. Organizational culture is components of organization, including values, beliefs, assumptions, perceptions, and behavior norms that are reflected in behavior of each organization member. There are three types of organizational cultures that are observed in this study, a) bureaucratic culture, hierarchical and fragmented (compartmentalized) in nature and there are clear lines for responsibility and authority of each staff organization, b) Innovative culture that promotes creativity, results-oriented, and prioritize a challenge in the work environment, and c) supportive culture that promotes teamwork, humanity orientation, friendship, hope and trust in the work environment (Wallach, 1983). Studies of Renyowijoyo (2003) showed there is a relationship between supportive organizational culture, innovative organizational culture, and bureaucratic organizational culture as well as work satisfaction (Handoko et al., 2011; Mohelska \& Sokolova, 2016).

The difference between authors' opinions is more terminological. The similarity of both theories is reflected in Table 1 .

Table 1. Characterization of K. Cameron, R. Quinn and E. Wallach organizational culture types/dimensions (source: Dubkevics \& Barbars, 2010)

\begin{tabular}{|l|c|l|c|}
\hline $\begin{array}{c}\text { Organizational culture } \\
\text { types by K. Cameron } \\
\text { and R. Quinn }\end{array}$ & $\begin{array}{c}\text { Organizational } \\
\text { culture dimensions } \\
\text { by E. Wallach }\end{array}$ & $\begin{array}{c}\text { Core values of the } \\
\text { organizational culture } \\
\text { (HRM environment) }\end{array}$ & $\begin{array}{c}\text { Individual motivation for } \\
\text { development of the of } \\
\text { human resource potential } \\
\text { (McClelland, 1967) }\end{array}$ \\
\hline $\begin{array}{l}\text { Hierarchy (similar to } \\
\text { market but characterized } \\
\text { with a stronger market } \\
\text { orientation) }\end{array}$ & Bureaucratic & $\begin{array}{l}\text { Efficiency, results } \\
\text { orientation, stability, } \\
\text { power, control, loyalty } \\
\text { and competition }\end{array}$ & Power \\
\hline Adhocracy & Innovative & $\begin{array}{l}\text { Personal creative } \\
\text { freedom, orientation } \\
\text { towards change, } \\
\text { innovation and risk }\end{array}$ & Achievement \\
\hline $\begin{array}{l}\text { Clan (family type } \\
\text { culture) }\end{array}$ & Supportive & $\begin{array}{l}\text { Unity ("we" con- } \\
\text { sciousness), team, } \\
\text { loyalty, and mutual } \\
\text { respect }\end{array}$ & Affiliation \\
\hline
\end{tabular}

In the discourse of the last decade, we have seen conflicting conclusions about the impact of international competition. In general, the positive impact of international competition on the likelihood that the company is conducting innovation can be seen in France, Germany, Spain, the UK and Estonia (Griffith, Huergo, Mairesse, \& Peters, 2006; Masso \& Vahter, 2008). With more detailed breakdown of the international competition indicators we can see that larger countries such se Germany and France (Griffith et al., 2006) and Finland (Ebersberger \& Lööf, 2004) are more likely to innovate even higher innovation intensity (R\&D spending per employee) mainly in firms oriented on their own domestic market compared to firms focusing on foreign markets. In smaller countries such as Norway and Sweden (Griffith et al., 2006), the Netherlands and Denmark (Ebersberger \& Lööf, 2004), is a reverse trend, 
i.e. higher innovation intensity of companies oriented on distant foreign markets. From the analysis of the specific services and manufacturing sector in the Netherlands (Polder \& Veldhuizen, 2012) and Sweden (Lööf \& Heshmati, 2006) we can infer that larger enterprises (250+ employees) are more likely to continually innovate products and processes in company. But regarding the innovation intensity, we can observe tendency to neglect the company size, or a negative effect with the size of the firm appears. For completeness, it should be added that many studies do not take into account enterprises with less than 50 employees. Elasticity of innovation intensity is a variable expressing the efficiency of the conversion of expenditure related to scientific research activities into the final product of innovation (for example an innovative product). This ranges from $26.7 \%$ in Russia to high $61.4 \%$ in Sweden's service sector (Lööf \& Heshmati, 2006). For the Czech Republic, there is an estimated value of around 14.6\% (Zemplinerová \& Hromádková, 2012) for the whole national industry or lower in case of the manufacturing industry. Elasticity in the Czech Republic is significantly lower than the observed interval of 72 in more developed countries (Vokoun, 2016). The study results basically confirm this.

\section{Research objective and methodology}

Research methodology and objectives are formulated in this chapter.

\subsection{Objectives and research question}

The primary objective of the paper is to examine the level of organizational culture in the Czech Republic and to seek appropriate managerial approaches to the development of organizational culture that can support the environment for innovation in the organization, therefore facilitating entrepreneurship in the Industry 4.0 concept. This objective can be divided into several sub-objectives:

$\mathrm{C} 1$ : To explore and present the concept of Industry 4.0 in connection with the use of appropriate managerial approaches to the development of an organizational culture supporting the process of innovation in organizations, i.e. introducing the Industry 4.0 concept (see Chapter 1 ).

C2: To analyze the level of organizational culture in organizations in the Czech Republic.

C3: Based on the findings, to carry out a discussion and formulate recommendations to strengthen organizational culture supporting Industry 4.0.

In connection with the objectives of the paper, a research question has been determined which examines organizational culture in the Czech Republic in the context of the 4th Industrial Revolution:

RQ: Does organizational culture in organizations in the Czech Republic support the introduction of the Industry 4.0 concept? Is the perception of the respondents different by gender and age?

Hypotheses - Since the respondents' perceptions may differ by both gender as well as their age, we have decided to verify the following hypotheses:

$\mathrm{H} 1$ : The distribution of bureaucratic culture is the same across gender categories. 
$\mathrm{H} 2$ : The distribution of bureaucratic culture is the same across age-group categories.

H3: The distribution of innovative culture is the same across gender categories.

H4: The distribution of innovative culture is the same across age-group categories.

H5: The distribution of supportive culture is the same across gender categories.

H6: The distribution of supportive culture is the same across age-group categories.

\subsection{Research and research methods}

In order to analyze organizational culture in organizations in the Czech Republic, the same study was carried out repeatedly in two-year cycles, i.e. 2013, 2015 and 2017.

For research, the form of a questionnaire survey was chosen as the most appropriate method - specifically, the Czech translation of Wallach's Questionnaire (1983) - Organizational Culture Index (OCI). Ellen J. Wallach has differentiated organizational culture into three dimensions - bureaucratic, supportive, and innovative. Bureaucratic culture is a prominent hierarchical organization, with a clearly defined line of authority, and highly organized (Wallach, 1983). On the other hand, the supportive culture focuses on interpersonal relationships. It is characterized by mutual trust, encouragement and co-operation. Finally, innovative culture is dynamic, supports creative work, brings new challenges and encourages risky behavior.

The questionnaire itself included four sections:

- Three demographic issues: gender, age and level of education of the respondent;

- Five questions concerning the organization's characteristics in which the respondent works: ownership of an organization (Czech ownership, foreign ownership, international corporations and public/governmental organizations), size of the organization (up to 50 employees, up to 250 employees, up to 500 employees and over 500 employees), and the position of the respondent (manager - with employee supervisory responsibility, employee without employee supervisory responsibility) and business area;

- The level of organizational culture - Czech translation of Wallach Questionnaire (1983) - Organizational Culture Index (OCI) (Wallach, 1983). The questionnaire consists of 24 items describing the organization. It is evaluated on Likert's four-point scale with answers from 0 (does not describe our organization) to 3 (describes our organization in most cases). The responses are evaluated for each dimension of organizational culture (eight items per dimension);

- A survey of work satisfaction was also part of the survey carried out - the results are not included in this paper.

Sample of respondents - the project's objective was to create a sample of employees from different fields, profit and non-profit sectors. Because it was not possible to obtain a crosssectional sample, the data was gathered through collaboration with college students of parttime studying program. It used the fact that these students work in different types of organizations within at least three regions of the Czech Republic.

The data used in this study was always collected in January and February in 2013, 2015, and 2017. Students of the Bachelor's degree of part time studying programs in selected cours- 
es at the Faculty of Informatics and Management at the University of Hradec Králové were asked to take the questionnaire to be filled by their work colleagues. Typically, each college student chose about 15 questionnaires. The respondents' description is given in the chapter Evaluation and Discussion.

Statistical analyses were performed using the software Statistica 8.

In order to verify whether there are statistically significant gender differences in the assessment of individual organizational culture dimensions, a Mann-Whitney $U$ test was used to evaluate unpaired attempts when comparing two different sample sets, in this case a set of evaluations of women and men. The null hypothesis is rejected $<0.05$.

To verify that there are statistically significant age differences in the assessment of individual organizational culture dimensions, the Kruskal-Wallis test was chosen. The KruskalWallis test is a generalization of the nonparametric Mann-Whitney test for more than two compared groups. As well as the Mann-Whitney test, it does not test the consistency of specific parameters, but the consistency of the selective distribution functions of the compared files, with the key assumption being that the observed values are independent. The null hypothesis is rejected $<0.05$.

Study limitations - Several limitations have been explored. The first of these is certainly a sample of respondents. However, this limitation is not significant because the Czech Republic currently has a relatively homogeneous socio-economic composition. Another limitation is that the category for employees with lower level education was not sufficiently represented in our sample. The method of data collection through part-time studying students may also be a limitation. However, this deficiency partially removes the diversification of the jobs these students have because they worked in different areas of the private and public/government sectors.

Despite these limitations, we are convinced that our data provides results that broaden our knowledge of organizational culture dimensions in organizations in the Czech Republic.

\section{Results and hypotheses verification}

The main results of the research are presented in the following part, as well as the evaluation of the formulated hypothesis.

\subsection{Results}

In total, the studies in 2013, 2015 and 2017 were attended by 1,950, 1,547 and 1,574 respondents, i.e. 174, 77 and 98 questionnaires were excluded from the sample due to various errors and missing values.

Respondents were aged 17-74 years in 2013, i.e. 16-77 years in the same period in 2015 and 2017 and their average age was 36.3 years $(S D=10.80)$, i.e. 36.19 years $(S D=10.70)$ and 36.36 years $(S D=11.45)$. Other selected respondent characteristics are given in Table 2.

The respondents mostly lived in the north-eastern regions of the Czech Republic - the regions of Hradec Králové, Pardubice and partly also Vysočina (the Czech Republic consists of 14 regions). 
Table 2. The surveyed sample's selected characteristics (source: Prepared by the authors)

\begin{tabular}{|l|c|c|c|c|c|c|}
\hline \multirow{2}{*}{ Item } & \multicolumn{2}{|c|}{2013} & \multicolumn{2}{c|}{2015} & \multicolumn{2}{c|}{2017} \\
\cline { 2 - 7 } & Percentage & Frequency & Percentage & Frequency & Percentage & Frequency \\
\hline \multicolumn{7}{|c|}{ Gender } \\
\hline Males & 42.9 & 762 & 42.1 & 619 & 45.7 & 675 \\
\hline Females & 57.1 & 1,014 & 57.9 & 851 & 54.3 & 801 \\
\hline \multicolumn{7}{|c|}{ Age } \\
\hline Under 30 & 32.4 & 576 & 32.4 & 476 & 35.6 & 525 \\
\hline 30-40 & 35.2 & 625 & 34.7 & 510 & 29.2 & 431 \\
\hline 41 or above & 32.4 & 575 & 32.9 & 484 & 35.2 & 520 \\
\hline \multicolumn{7}{|c|}{ Years of experience (tenure) } \\
\hline Under 5 years & 44.0 & 781 & 42.2 & 621 & 48.8 & 721 \\
\hline 5-10 years & 29.5 & 524 & 29.9 & 440 & 27.2 & 401 \\
\hline $11-15$ years & 11.9 & 211 & 12.9 & 190 & 10.8 & 160 \\
\hline Over 15 years & 14.6 & 260 & 14.9 & 219 & 13.1 & 194 \\
\hline
\end{tabular}

From the characteristics below, it is clear that the surveyed samples of respondents are comparable in all surveys.

Organic culture index (OCI) was used to measure organizational culture in organizations in the Czech Republic. The respondents rated 24 items - risk taking, collaborative, hierarchical, procedural, relationship-oriented, results-oriented, creative, encouraging, sociable, structure, pressurized, ordered, stimulating, regulated, established - solid, cautious, trusting, driving and power-oriented - on Likert's four-point scale with responses from 0 (doesn't describe our organization) to 3 (describes our organization in most cases). Subsequently, the responses were evaluated for each dimension of organizational culture, each dimension was described in 8 items.

The results of the individual characteristics are presented in Figures 1-3. These characteristics are already divided according to their membership in the individual dimensions of the organizational culture.

At first glance at the above results, it's already clear that the respondents characterize the organizations where they work, with characteristics that are typical of bureaucratic culture according to Wallach, subsequently supportive, the characteristics of innovative culture are least perceived. For bureaucratic and supportive organizational culture, the average rating is around 1.9 (the maximum rating is 3 ). For the characteristics of the innovation culture, the average value for all three surveys is below 1.5 .

It is also interesting to note that the perception of the individual determinants of organizational culture have hardly changed at all over time, but the differences are not significant at all.

If we were to choose the five main characteristics that describe the organizations surveyed across all dimensions, we would say that respondents perceive today's organizations mainly as being established - solid, regulated, results-oriented, safe and collaborative. 


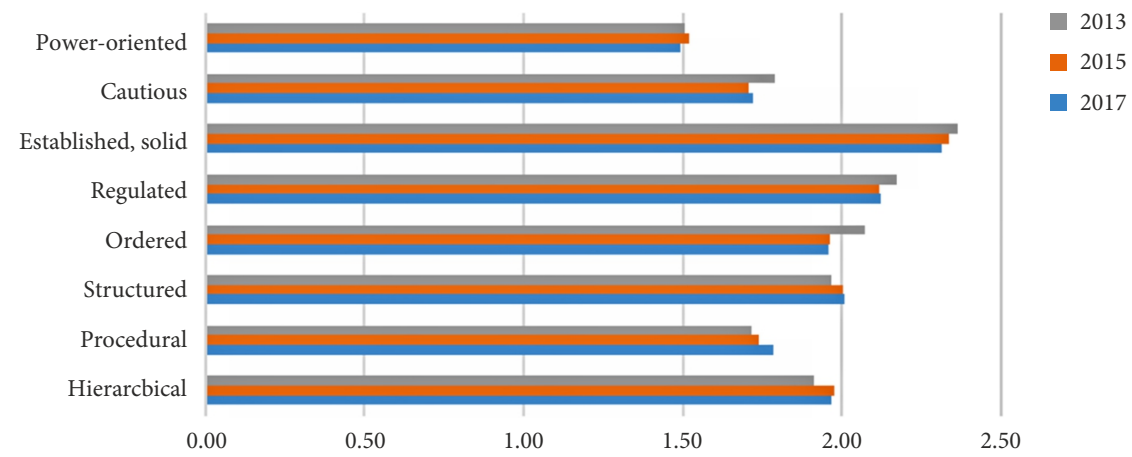

Figure 1. Bureaucratic culture characteristics according to Wallach (1983) (source: Prepared by the authors)

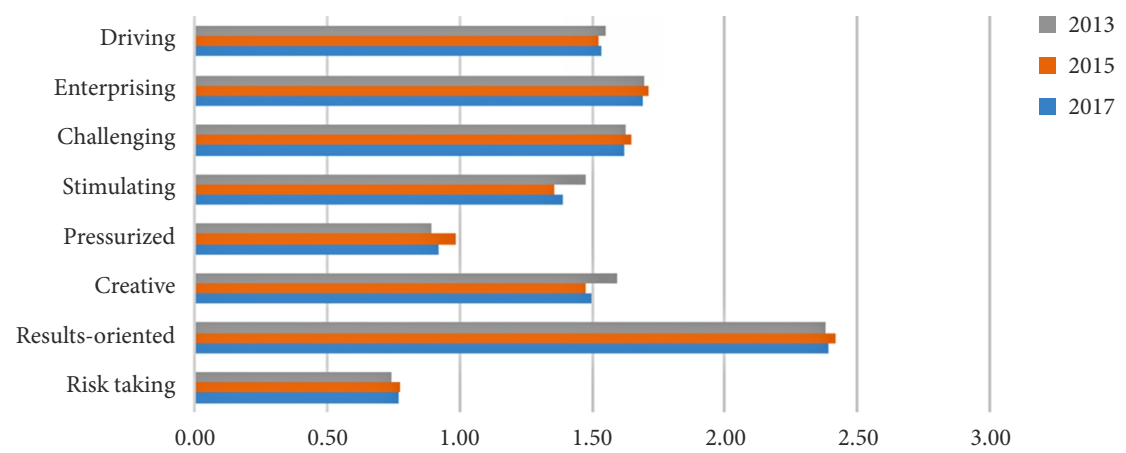

Figure 2. Innovative culture characteristics according to Wallach (1983) (source: Prepared by the authors)

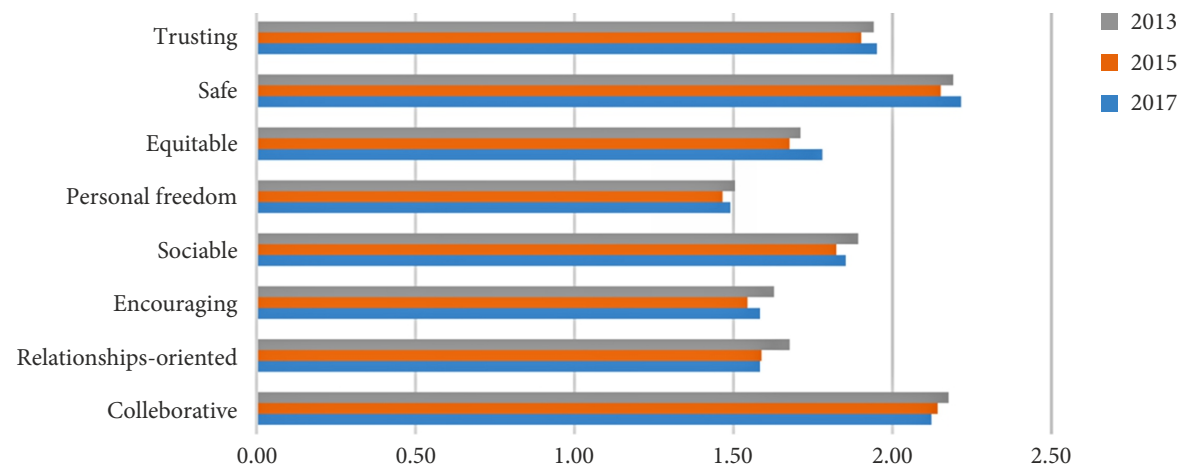

Figure 3. Supporting culture characteristics according to Wallach (1983) (source: Prepared by the authors)

In the following table (Table 3), we can already see the Organizational Culture Index values by Wallach, confirming the above values by one value. The highest index belongs to bureaucratic organizational culture, followed by a supportive culture. The signs of innova- 
tive culture are not so remarkable from the viewpoint of the respondents, according to the organizational culture index the innovation culture ended up in third place, with a more significant distance.

The following figure (Figure 4) it is also shown in a graphical form.

As noted above, the respondents are more likely to understand and perceive culture in organizations as more bureaucratic and supportive. Figure 5 shows that this initial findings of 2013 in the subsequent survey were confirmed, as the differences in the observed organizational culture index are by no means significant.

Table 3. Organizational culture index according to Wallach - in 2013, 2015 and 2017 (source: Prepared by the authors)

\begin{tabular}{|l|c|c|c|}
\cline { 2 - 4 } \multicolumn{1}{c|}{} & 2013 & 2015 & 2017 \\
\hline Bureaucratic culture & 15.50 & 15.37 & 15.37 \\
\hline Innovative culture & 11.96 & 11.89 & 11.81 \\
\hline Supportive culture & 14.72 & 14.29 & 14.58 \\
\hline
\end{tabular}

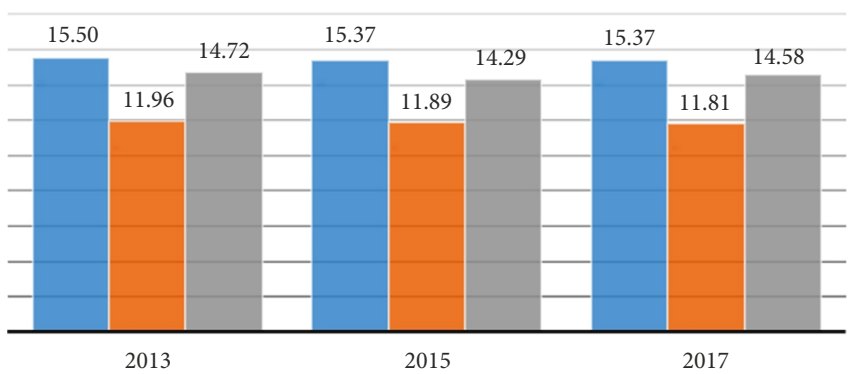

Bureaucratic culture

Innovative culture

- Supportive culture

Figure 4. Organizational culture index according to Wallach - 2013, 2015 and 2017 (source: Prepared by the authors)

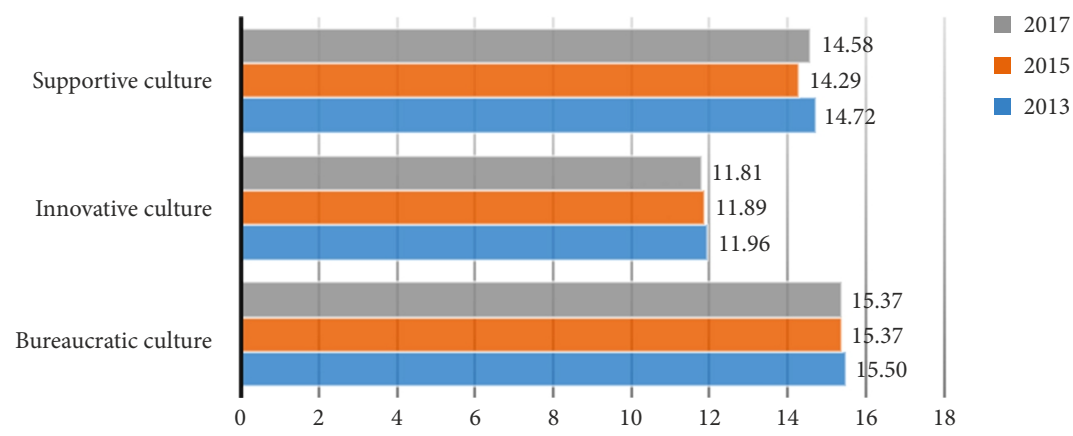

Figure 5. Organizational cultures index - Development in the years (source: Prepared by the authors) 


\subsection{Hypotheses verification}

In order to verify hypotheses regarding gender differences in the assessment of individual dimensions of organizational cultures, the Mann-Whitney U test was chosen and the KruskalWallis test was chosen to verify age differences.

The respondents were divided into three age-groups up to 29, 30 to 40 and 41 and over.

The results of individual hypotheses broken down by organizational culture dimensions are shown in the Tables 4-6.

Regarding the gender vasriable, the null hypothesis was not reversed in bureaucratic and supportive culture. For innovative culture, the hypothesis was rejected in 2013 and 2017, but after a deeper analysis it can be concluded that the deviations are insignificant and that the significance of the differences can be attributed to the size of the sample, it is appropriate to doubt the real meaning.

Table 4. Hypotheses verification - bureaucratic culture (source: Prepared by the authors)

\begin{tabular}{|l|c|c|c|l|}
\hline \multicolumn{1}{|c|}{ Null Hypothesis } & Test & Year & Sig. & \multicolumn{1}{|c|}{ Decision } \\
\hline \multirow{2}{*}{$\begin{array}{l}\text { The distribution of bureaucratic } \\
\text { culture is the same across } \\
\text { categories of gender }\end{array}$} & \multirow{2}{*}{$\begin{array}{c}\text { Mann-Whitney } \\
\text { U test }\end{array}$} & 2013 & 0.501 & Retain the null hypothesis \\
\cline { 3 - 6 } & & 2015 & 0.256 & Retain the null hypothesis \\
\cline { 3 - 6 } $\begin{array}{l}\text { The distribution of bureaucratic } \\
\text { culture is the same across } \\
\text { categories of agegroup }\end{array}$ & \multirow{2}{*}{$\begin{array}{c}\text { Kruskal-Wallis } \\
\text { test }\end{array}$} & 2013 & 0.918 & Retain the null hypothesis \\
\cline { 3 - 6 } & 2015 & 0.112 & Retain the null hypothesis \\
\cline { 3 - 6 } & & 2017 & 0.334 & Reject the null hypothesis \\
\hline
\end{tabular}

Table 5. Hypotheses verification - innovative culture (source: Prepared by the authors)

\begin{tabular}{|l|c|c|c|c|}
\hline \multicolumn{1}{|c|}{ Null Hypothesis } & Test & Year & Sig. & Decision \\
\hline The distribution of innovative & \multirow{2}{*}{$\begin{array}{c}\text { Mann-Whitney } \\
\text { culture is the same across } \\
\text { categories of gender }\end{array}$} & 2013 & 0.000 & Reject the null hypothesis \\
\cline { 3 - 6 } & 2015 & 0.148 & Retain the null hypothesis \\
\cline { 3 - 6 } & 2017 & 0.025 & Reject the null hypothesis \\
\hline $\begin{array}{l}\text { The distribution of innovative } \\
\text { culture is the same across } \\
\text { categories of agegroup }\end{array}$ & \multirow{2}{*}{$\begin{array}{c}\text { Kruskal-Wallis } \\
\text { test }\end{array}$} & 2013 & 0.005 & Reject the null hypothesis \\
\cline { 3 - 6 } & 2015 & 0.000 & Reject the null hypothesis \\
\cline { 3 - 6 } & 2017 & 0.009 & Reject the null hypothesis \\
\hline
\end{tabular}

Table 6. Hypotheses verification - supporting culture (source: Prepared by the authors)

\begin{tabular}{|l|c|c|c|c|}
\hline \multicolumn{1}{|c|}{ Null Hypothesis } & Test & Year & Sig. & Decision \\
\hline The distribution of supportive & \multirow{2}{*}{$\begin{array}{c}\text { Mann-Whitney } \\
\text { culture is the same across }\end{array}$} & 2013 & 0.722 & Retain the null hypothesis \\
\cline { 5 - 6 } & U test & 2015 & 0.331 & Retain the null hypothesis \\
\cline { 3 - 6 } & 2017 & 0.484 & Retain the null hypothesis \\
\hline \multirow{2}{*}{$\begin{array}{l}\text { The distribution of supportive } \\
\text { culture is the same across } \\
\text { categories of agegroup }\end{array}$} & \multirow{2}{*}{$\begin{array}{c}\text { Kruskal-Wallis } \\
\text { test }\end{array}$} & 2013 & 0.038 & Reject the null hypothesis \\
\cline { 3 - 6 } & & 2015 & 0.033 & Reject the null hypothesis \\
\cline { 3 - 6 } & & 2017 & 0.012 & Reject the null hypothesis \\
\hline
\end{tabular}


Age differences are not just significant in bureaucratic culture in 2013 and 2017. For other hypotheses, age difference is significant. An important difference is in the youngest group, where the culture is always above the expected average for an innovative and supportive culture, the opposite effect can be seen in the oldest age group. There can be more explanations, for example, younger people are more involved in organizations with innovative and supportive culture and older people are more involved in organizations with traditional bureaucratic culture. It can also be due to the fact that young people perceive the culture of organizations as innovative and supportive, older people are in the organization longer and have their stereotypes established and they do not perceive the culture of the company as innovative.

\section{Discussion}

In addition, the implementation of the Industry 4.0 concept necessitates involvement from top management promoting comprehensive change management activities and processes for arranging organizational and production structures according to the needs of the connected value creation. A collaborative, explorative, and entrepreneurial mind-set is a success factor that is necessary to establish among a company's most important resource: the employees. Managers should have willingness to convince employees of the beneficial nature of Industry 4.0 and to address their concerns actively. With concern to this fact, employees' training and development should be directed towards Industry 4.0's specific competencies and skills, such as data analytics, IT, software, and human-machine interaction know-how. Finally, Industry 4.0 provides economic, environmental, as well as social benefits and opportunities (Dubkevics \& Barbars, 2010).

Generally, the data gained from selected enterprises indicates that awareness in Czech companies is quite high with regard to the existence of a trend known as Industry 4.0. This readiness mainly manifests itself at upper management level rather than with the average employee level. Companies still lack their own Industry 4.0 strategy and they have not assigned responsible personnel to take care of further deepening of Industry 4.0 principles. So far, a higher penetration of Industry 4.0 principles into companies is inhibited by unclear benefits and in many cases the high costs associated with the Industry 4.0 solutions application. Industry 4.0 is also among the topics that are being strategically initiated and supported by top management in their visions and which are motivated by the customer demands and are expected to bring lower costs. Finally, the investigation shows that there is a large area for improvement in terms of delivery of the available information on Industry 4.0 to the employees. Most companies (56\%) stated that their employees aren't yet aware that this new trend (Industry 4.0) is already part of the their employees' motivation (Basl, 2017).

Measuring results with regard to the training and development of human resources, or developing the company's knowledge culture, may be just as important as (possibly more important than) measuring the financial or technological results, for innovation performance measurement (Žižlavský, 2013). Innovations productivity tends to not only be conditioned by the volume of research and development (R\&D) expenditures, but also by a company's capacity for coordinating human resources, as one example, or for resolving technical problems, as another. There are many literature studies demonstrating the influence of the human 
resources on the performance of innovation (Cabello-Medina, López-Cabrales, \& Valle-Cabrera, 2011; Sokolová, Mohelská, \& Zubr, 2016). Specifically, such studies coincide in noting positive influences on the effectiveness of the company's R\&D of the knowledge, abilities and skills of the staff employed in the R\&D department; positive indicators of these factors is having a relatively high percentage of total employees working in the R\&D department, and presenting a high degree of aptitude, professionalism and training the staff (Souitaris, 2002). Another important factor analyzed in the literature in regard to innovation performance is employees' motivation for creativity and innovation (Çekmecelioğlu \& Günsel, 2013). Finally, the climate in the close human relationships that are formed in $\mathrm{R} \& \mathrm{D}$ departments is also considered to be a factor that encourages the creation of innovations value, and the improvements in the internal processes taking place in this activity (Žižlavský, 2016).

\section{Conclusions}

By analysing the Industry 4.0 studies published so far, it has been discovered that they mostly discuss the technical aspects but do not pay attention to managerial approaches and organisational culture that are a significant factor influencing the success of the implementation of this concept. Implementing the Industry 4.0 concept requires continuous innovation and education that not only depend on people's abilities but also on organisational culture. The results of the extensive survey conducted in the Czech Republic show that respondents perceive organisational culture in the research organisations as more bureaucratic and supportive rather than innovative. The characteristics of innovative culture are not so striking in their view. A deeper analysis revealed that there are no significant differences in perceptions of women and men. Certain differences in perception are apparent in terms of age. A significant difference is in the youngest group, where the culture is always above the expected average for an innovative and supportive culture, the opposite effect can be seen in the oldest age group.

Research question: "Does the organisational culture in organisations in the Czech Republic support the introduction of the Industry 4.0 concept?". Can be answered negatively on the basis of the findings. Therefore, it is necessary to change managerial approaches to support the innovative solutions that are required to effectively implement and operate the Industry 4.0 concept.

\section{Acknowledgements}

The paper is supported by the specific project 6/2018 "Determinants of cognitive processes impacting the work performance" and the project Excellence (2203/2018) at the Faculty of Informatics and Management of the University of Hradec Kralove, Czech Republic. Thanks to help of students Alice Vinterova, and Tomáš Valenta.

\section{Author contributions}

Alice Vinterova and Tomáš Valenta. 


\section{Funding}

This work was supported by the University of Hradec Kralove under the specific project $6 / 2018$ grant "Determinants of cognitive processes impacting the work performance" and the project Excellence (2203/2018).

\section{References}

Armstrong, M. (2006). A handbook of human resource management practice (10th ed). London, Philadelphia: Kogan Page.

Arnold, C., Kiel, D., \& Voigt, K. I. (2016). How the industrial internet of things changes business models in diferent manufacturing industries. International Journal of Innovation Management, 20(08), 1640015. https://doi.org/10.1142/S1363919616400156

Basl, J. (2017). Pilot study of readiness of Czech companies to implement the principles of Industry 4.0. Management and Production Engineering Review, 8(2). https://doi.org/10.1515/mper-2017-0012

Bauer, W., Schlund, S., Marrenbach, D., \& Ganschar, O. (2014). Industry 4.0 - Volkswirtschaftliches Potenzial für Deutschland. BITKOM, Berlin.

Brettel, M., Friederichsen, N., Keller, M., \& Rosenberg, M. (2014). How virtualization, decentralization and network building change the manufacturing landscape: an Industry 4.0 perspective. International Journal of Mechanical, Aerospace, Industrial and Mechatronics Engineering, 8(1), 37-44.

Cabello-Medina, C., López-Cabrales, Á., \& Valle-Cabrera, R. (2011). Leveraging the innovative performance of human capital through HRM and social capital in Spanish firms. The International Journal of Human Resource Management, 22(4), 807-828. https://doi.org/10.1080/09585192.2011.555125

Çekmecelioğlu, H. G., \& Günsel, A. (2013). The effects of individual creativity and organizational climate on firm innovativeness. Procedia - Social and Behavioral Sciences, 99, 257-264. https://doi.org/10.1016/j.sbspro.2013.10.493

Dubkevics, L., \& Barbars, A. (2010). The role of organisational culture in human resource management. Human Resources Management \& Ergonomics, IV(1), 1-10.

Ebersberger, B., \& Lööf, H. (2004). Multinational enterprises, spillovers, innovation and productivity. Royal Institute of Technology, CESIS - Centre of Excellence for Science and Innovation Studies. Retrieved from https://ideas.repec.org/p/hhs/cesisp/0022.html

Griffith, R., Huergo, E., Mairesse, J., \& Peters, B. (2006). Innovation and productivity across four European countries. Oxford Review of Economic Policy, 22(4), 483-498. https://doi.org/10.1093/oxrep/grj028

Handoko, Y., Setiawan, M., \& Surachman, D. (2011). Organizational Culture, Job Satisfaction, Organizational Commitment, the Effect on Lecturer Performance. International Journal of Business and Management Invention, 2(12), 21-30.

Háša, S., \& Brunet-Thornton, R. (Eds.). (2017). Impact of organizational trauma on workplace behavior and performance. IGI Global Disseminator of Knowledge. https://doi.org/10.4018/978-1-5225-2021-4

Hecklau, F., Galeitzke, M., Flachs, S., \& Kohl, H. (2016). Holistic Approach for Human Resource Management in Industry 4.0. Procedia CIRP, 54, 1-6. https://doi.org/10.1016/j.procir.2016.05.102

Kagermann, H., Wahlster, W., \& Helbig, J. (2013). Recommendations for implementing the strategic initiative INDUSTRY 4.0. National Academy of Science and Engineering, Berlin/Frankfurt.

Lööf, H., \& Heshmati, A. (2006). On the relationship between innovation and performance: A sensitivity analysis. Economics of Innovation and New Technology, 15(4-5), 317-344.

https://doi.org/10.1080/10438590500512810 
Masso, J., \& Vahter, P. (2008). Technological innovation and productivity in late-transition Estonia: econometric evidence from innovation surveys (Working Paper No. 61-2008). The University of Tartu Faculty of Economics and Business Administration. https://doi.org/10.2139/ssrn.1126281

McClelland, D. C. (1967). The achieving society by David C. McClelland. Free Press.

Mohelska, H., \& Sokolova, M. (2016). Smart, connected products change a company's business strategy orientation. Applied Economics, 48(47), 4502-4509. https://doi.org/10.1080/00036846.2016.1158924

Mustafa Elqadri, Z., \& Priyono, D. (2015). The influence of organizational culture, organizational climate, and the promotion of the position of employee job satisfaction in PT. Surabaya Graphics Media Temprina. Asian Social Science, 11(22), 139-148. https://doi.org/10.5539/ass.v11n22p139

Osborne, S. P., \& Brown, K. (2005). Managing change and innovation in public service organizations (1st ed). London, New York: Routledge. https://doi.org/10.4324/9780203391129

Pagáč, M. (2015). What does the fourth industrial revolution mean? Retrieved from https://www.konstrukter.cz/2015/10/29/co-znamena-ctvrta-prumyslova-revoluce/

Polder, M., \& Veldhuizen, E. (2012). Innovation and competition in the Netherlands: testing the inverted-U for industries and firms. Journal of Industry, Competition and Trade, 12(1), 67-91. https://doi.org/10.1007/s10842-011-0120-7

Prause, G., \& Atari, S. (2017). On sustainable production networks for Industry 4.0. Entrepreneurship and Sustainability Issues, 4(4), 421-431. https://doi.org/10.9770/jesi.2017.4.4(2)

Qin, J., Liu, Y., \& Grosvenor, R. (2016). A categorical framework of manufacturing for Industry 4.0 and beyond. Procedia CIRP, 52, 173-178. https://doi.org/10.1016/j.procir.2016.08.005

Rennung, F., Luminosu, C. T., \& Draghici, A. (2016). Service provision in the framework of Industry 4.0. Procedia - Social and Behavioral Sciences, 221, 372-377. https://doi.org/10.1016/j.sbspro.2016.05.127

Renyowijoyo, M. (2003). The relationship between organizational culture, organizational commitment, job satisfaction and employee performance: empirical study employee manufacturing sector in Indonesia (Doctoral dissertation). Universiti Utara Malaysia.

Schein, E. H. (2004). Organizational culture and leadership (3rd ed). San Francisco: Jossey-Bass.

Schneider, S., \& Spieth, P. (2013). Business model innovation: towards an integrated future research agenda. International Journal of Innovation Management, 17(01), 1340001. https://doi.org/10.1142/S136391961340001X

Sokolová, M., Mohelská, H., \& Zubr, V. (2016). Pay and offer of benefits as significant determinants of job satisfaction - a case study in the Czech Republic. E+M Ekonomie a Management, 19(1), 108120. https://doi.org/10.15240/tul/001/2016-1-008

Souitaris, V. (2002). Firm-specific competencies determining technological innovation: A survey in Greece. $R$ \& D Management, 32(1), 61-77. https://doi.org/10.1111/1467-9310.00239

Voigt, K. I., Buliga, O., \& Michl, K. (2017). Business model pioneers: how innovators successfully implement new business models. Cham: Springer. https://doi.org/10.1007/978-3-319-38845-8

Vokoun, M. (Ed.). (2016). Analysis of innovation activities of enterprises (1. vydání). Praha: Setoutbooks.cz.

Wallach, E. J. (1983). Individuals and organizations: The cultural match. Training and Development Journal, 12, 28-36.

Widyarini, M. M. N. (2009). Popular psychology series: keys to self development. Jakarta: PT Elex Media Komputindo.

Zemplinerová, A., \& Hromádková, E. (2012). Determinants of firm’s innovation. Prague Economic Papers, 21(4), 487-503. https://doi.org/10.18267/j.pep.436

Žižlavský, O. (2013). Past, present and future of the innovation process. International Journal of Engineering Business Management, 5(47), 1-8. https://doi.org/10.5772/56920

Žižlavský, O. (2016). Innovation scorecard: conceptual performance measurement and management framework for innovation process. Journal of Global Business \& Technology, 12(2), 10-27. 